\title{
A survey of the practice of after-hours and emergency endoscopy in Canada
}

\author{
Karuppan Chetty Muthiah MD FRCPC ${ }^{1}$, Robert Enns MD FRCPC 2,3 , David Armstrong MA MB BChir FRCPC ${ }^{2,4}$, \\ Angela Noble MD FRCPC 2,5 , James Gray MD FRCPC ${ }^{2,3}$, Paul Sinclair MSc ${ }^{2}$, \\ Palma Colacino ${ }^{2}$, Harminder Singh MD MPH FRCPC $1,2,6,7$
}

KC Muthiah, R Enns, D Armstrong, et al. A survey of the practice of after-hours and emergency endoscopy in Canada. Can J Gastroenterol 2012;26(12):871-876.

OBJECTIVE: To determine staffing and practice patterns for afterhours endoscopy service in Canada

METHODS: A link to a web-based survey was sent by e-mail to all clinical members of the Canadian Association of Gastroenterology in February 2011. A priori, it was planned to compare variations in practice among gastroenterologists (GIs) performing endoscopy in different regions of Canada, between pediatric and adult GIs, and between university and community hospitals.

RESULTS: Of 422 potential respondents, 168 (40\%) responded. Of the 139 adult GIs, $61 \%$ performed after-hours endoscopy in the endoscopy suite where daytime procedures were performed, $62 \%$ had a trained endoscopy nurse available for all procedures, $38 \%$ had access to propofol sedation, $12 \%$ reprocessed the endoscopes themselves or with the help of a resident, $4 \%$ had out-of-hospital patients come directly to their endoscopy suite and $53 \%$ were highly satisfied. The adult endoscopists practising at community hospitals were more likely to have an anesthetist attend the procedure. Regional differences were noted, with more involvement of anesthetists (13\%) and availability of propofol (50\%) in Ontario, more frequent reprocessing of endoscopes in the central reprocessing units in British Columbia (78\%) and almost universal availability of a trained endoscopy nurse (96\%) with concomitant higher endoscopist satisfaction (84\% highly satisfied) in Alberta.

CONCLUSIONS: More than one-third of surveyed endoscopists across the country do not have a trained endoscopy nurse to assist in after-hours endoscopy - the time period when urgent patients often present and typically require therapeutic endoscopic interventions. There are significant regional differences in the practice of after-hours endoscopy in Canada.

Key Words: Emergency care; Endoscopy; Staffing; Standards

$\mathrm{M}$ ost of the endoscopies performed after regular work hours (ie, 'after-hours' endoscopies) are performed for emergent indications such as gastrointestinal bleeding, esophageal food bolus impaction or cholangitis. Such emergency endoscopies generally involve performing the procedures on acutely ill patients often with hemodynamic instability that requires therapeutic intervention, as well as other comorbidities with risk of cardiorespiratory compromise. Recent Canadian and international guidelines have recommended appropriate staffing for emergency endoscopy as essential, but the appropriate level of staffing is not well-defined in any of them $(1,2)$. In a previous survey, focused primarily on sedation practices for colonoscopy across Canada, we found $97 \%$ of the respondents had at

\section{Un sondage de la pratique de l'endoscopie d'urgence et après les heures normales de travail au Canada}

OBJECTIF : Déterminer le personnel et les profils de pratique d'un ser-
vice d'endoscopie après les heures normales de travail au Canada
MÉTHODOLOGIE : En février 2011, tous les cliniciens de l'Association
canadienne de gastroentérologie ont reçu un cybersondage par courriel. A
priori, on prévoyait comparer les variations de pratique entre les gastroen-
térologues (GE) qui exécutaient des endoscopies dans diverses régions du
Canada, entre GE pour adultes et pour enfants et entre hôpitaux universi-
taires et généraux. RÉSULTATS : Sur les 422 répondants potentiels, 168 (40\%) ont répondu. Sur les $139 \mathrm{GE}$ pour adultes, $61 \%$ effectuaient des endoscopies après les heures normales de travail au bloc d'endoscopie où les interventions diurnes avaient lieu, $62 \%$ comptaient sur une infirmière d'endoscopie formée lors de toutes les interventions, $38 \%$ avaient accès à la sédation par propofol, $12 \%$ procédaient à la stérilisation de l'endoscope euxmêmes ou avec l'aide d'un résident, $4 \%$ voyaient des patients de l'extérieur de l'hôpital qui se présentaient directement au bloc d'endoscopie et $53 \%$ étaient hautement satisfaits. Les endoscopistes pour adultes qui exerçaient dans des hôpitaux généraux étaient plus susceptibles de compter sur la présence d'un anesthésiste lors de l'intervention. On a constaté des différences régionales, telles qu'une plus grande participation des anesthésistes (13\%) et l'accès au propofol (50\%) en Ontario, une stérilisation plus fréquente des endoscopes à l'unité de stérilisation centrale en Colombie-Britannique (78 \%) et l'accès presque universel à une infirmière d'endoscopie (96\%), accompagnée d'une plus grande satisfaction de l'endoscopiste (84 \% hautement satisfaits) en Alberta.

CONCLUSIONS : Plus du tiers des endoscopistes sondés au pays n'ont pas d'infirmière d'endoscopie formée pour les assister lors des endoscopies effectuées après les heures normales de travail, soit la période au cours de laquelle les urgences sont fréquentes et nécessitent généralement des interventions endoscopiques thérapeutiques. On constate des différences régionales importantes dans la pratique de l'endoscopie après les heures normales de travail au Canada.

least one trained endoscopy nurse present during routine endoscopy (3). Anecdotally, several hospitals have recently withdrawn the services of trained endoscopy nurses for after-hours endoscopy (communication from Canadian Association of Gastroenterology [CAG] members from Ontario). However, there are no systematically collected data on the practices for after-hours endoscopy in Canada or in other jurisdictions.

We conducted a survey to determine the staffing, practice patterns and level of satisfaction for after-hours endoscopy in Canada. The survey was performed on behalf of the CAG Clinical Affairs committee in accordance with its mandate to document and improve care for Canadians with gastrointestinal disorders.

\footnotetext{
${ }^{1}$ Internal Medicine, University of Manitoba, Winnipeg, Manitoba; ${ }^{2}$ Canadian Association of Gastroenterology Clinical Affairs Committee, Oakville, Ontario; ${ }^{3}$ Division of Gastroenterology, Department of Medicine, St Paul's Hospital, University of British Columbia, Vancouver, British Columbia;

${ }^{4}$ Division of Gastroenterology $\mathcal{E}$ Farncombe Family Digestive Health Research Institute, McMaster University, Hamilton; ${ }^{5}$ Pediatrics, Queen's

University, Kingston, Ontario; ${ }^{6}$ Community Health Sciences, University of Manitoba; ${ }^{7}$ University of Manitoba IBD Clinical and Research Centre, Winnipeg, Manitoba

Correspondence: Dr Harminder Singh, Section of Gastroenterology, University of Manitoba, 805-715 McDermot Avenue, Winnipeg, Manitoba R3E 3P4. Telephone 204-480-1311, fax 204-789-3972, e-mail singh@cc.umanitoba.ca

Received for publication May 28, 2012. Accepted June 4, 2012
} 


\section{METHODS}

The survey instrument was developed by the authors and first distributed to the members of the Division of Gastroenterology at the University of Manitoba (Winnipeg, Manitoba) to establish content and face validity. Modifications were made based on the responses and comments on the pilot assessment.

The final survey instrument consisted of six pages and 35 items divided into two sections (ie, demographics and after-hours endoscopy care practices). The demographics section included questions on primary specialty, province of practice and population of practice location. The second part included questions regarding after-hours staffing patterns, site of after-hours endoscopy, time allocated for emergency endoscopy, personnel reprocessing the endoscopes, access to propofol sedation and intensive care unit beds, acceptance of patients from other facilities, availability of endoscopic retrograde cholangiopancreatography (ERCP) call schedule and satisfaction level of the endoscopists for the current arrangements for after-hours endoscopy.

A link to the web-based survey was sent by e-mail to all clinical members of the CAG in February 2011. A reminder was sent four weeks later to improve the response rate. The e-mails were sent by the CAG National Office. All responses were anonymous and the investigators received no information that would identify the respondent or their site of practice.

Survey responses were collated in an Excel spreadsheet (Microsoft Corporation, USA). Cross tabulation was performed using SPSS version 19 (IBM Corporation, USA). Standard descriptive statistics were used to describe response frequency. The $\chi^{2}$ test was used to compare categorical variables and a two-sided $\mathrm{P}<0.05$ was considered to be statistically significant. The endoscopists' satisfaction with the current arrangements for after-hours endoscopy at their primary site was assessed on a 10-point Likert scale and the responses categorized as low (1 to 4 ), moderate (5 to 7 ) and high (8 to 10 ) satisfaction. A priori, it was planned to compare variations in practice among gastroenterologists (GIs) performing endoscopy in different regions of Canada, between pediatric and adult GIs, and between university and community hospitals. To ascertain regional variations, the comparison was performed among Ontario $(\mathrm{ON})$, Alberta $(\mathrm{AB})$, British Columbia (BC) and all the remaining provinces.

The present project was approved by the Ethics Board at the University of Manitoba.

\section{RESULTS}

Of the 422 potential respondents, 168 (40\%) responded. The response pattern across the country reflected the CAG membership, apart from a slightly higher response rate from BC (Table 1). Fifty-eight per cent $(n=78)$ of the respondents practised primarily in university hospitals, which is comparable with the $56 \%(n=238)$ of the CAG membership practising in university hospitals. Of the 168 respondents, $139(83 \%)$ were adult GIs, $18(10.7 \%)$ were pediatric GIs and the rest $(5.6 \%)$ were hepatologists, internists and/or family physicians. Only those performing after-hours endoscopy are included in the rest of the presented results.

\section{Adult versus pediatric GIs (Table 2)}

Although most of the GIs had at least one registered nurse present for after-hours endoscopy, a trained endoscopy nurse was available all of the time for only two-thirds of adult GIs and for only $12 \%$ of pediatric GIs; $25 \%$ of the adult GIs and $65 \%$ of the pediatric GIs had no on-call endoscopy nurse. Furthermore, 22\% of the adult GIs and $88 \%$ of the pediatric GIs had no set amount of time reserved for emergency cases in the daytime endoscopy schedules. Most GIs were able to arrange an endoscopy within $24 \mathrm{~h}$ of deciding that an endoscopy was indicated. Approximately $14 \%$ of the adult GIs clean and reprocess endoscopes themselves or with the help of their house staff.

All $(n=17)$ of the pediatric GIs practised at university hospitals. Most of the pediatric GIs (70\%) performed after-hours endoscopy in operating rooms, had an anesthetist present (65\%), access to propofol sedation (94\%) and intensive care unit beds (94\%). However, only $12 \%$ of the pediatric GIs were highly satisfied with the current arrangements for after-hours endoscopy compared with $53 \%$ of the adult GIs $(\mathrm{P}<0.01)$.

\section{University versus community hospitals (Table 3)}

A higher proportion of the respondents practising in university hospitals performed after-hours endoscopy in emergency rooms (91\%) or intensive care units (91\%) than those in the community hospitals. As can be expected, most endoscopists in the community hospitals performed endoscopy without house staff. A majority (58\%) at the community hospitals had the endoscopes processed in the central processing units. Approximately one-third of transfers from other hospitals were received by the endoscopy team in the emergency rooms of either type of facility. A small minority (7\%) at the community hospitals were unable to perform emergency endoscopy within $24 \mathrm{~h}$. Even at the university hospitals, only one-half of the endoscopists had an on-call schedule for ERCPs. There was no significant difference in the satisfaction rating between endoscopists at university and community hospitals.

\section{Regional variation (Table 4)}

Endoscopy nurse assistance outside the endoscopy units was available less often in ON than in the other provinces. The site of the performance of after-hours endoscopy also varied significantly across the country. Interestingly, two registered nurses were present more frequently for after-hours endoscopy in the rest of the country than in the three provinces analyzed separately. Trained endoscopy nurses were available almost all the time in $\mathrm{AB}$ and the rest of the country but only for approximately one-half of the after-hours endoscopy procedures in $\mathrm{ON}$ and $\mathrm{BC}$. A much higher proportion of respondents from $\mathrm{BC}$ had the endoscopes processed in central reprocessing units than in the other provinces. A lower proportion of respondents from $\mathrm{ON}$ were able to perform more than $75 \%$ of emergency endoscopies within $24 \mathrm{~h}$. In $\mathrm{ON}$, only a minority of the respondents performed after-hours endoscopy in the endoscopy suite where daytime procedures were performed. Furthermore, assistance by trained endoscopy nurses was available less often outside of the endoscopy units in ON. A much higher proportion of endoscopists in $\mathrm{AB}(84 \%)$ were highly satisfied compared with one-half or less in the other provinces $(\mathrm{P}=0.01)$

\section{DISCUSSION}

Results of the present survey suggest that there are large regional differences in the practice of after-hours endoscopy in Canada. The findings in $\mathrm{ON}$ and $\mathrm{BC}$ are concerning in that only one-half of the respondents have a trained endoscopy nurse present at all times for after-hours endoscopy.

The staff assisting during the performance of endoscopy provide several vital functions. These include administration of sedation, patient monitoring, documentation and technical assistance (4). The technical assistance includes manipulation of endoscopic accessory devices, such as cautery devices, proper deployment of endoscopic clips, and other hemostatic equipment and manipulation of the endoscopes, while the endoscopist performs complex tasks (5). The need for appropriate technical assistance is more common during emergency procedures when hemostatic interventions are performed at a much higher rate than during the regularly scheduled procedures. Yet, paradoxically, more endoscopists have well-trained assistants available during the regularly scheduled procedures than for after-hours endoscopy!

One of the potential reasons for such wide variations in staffing for after-hours endoscopy may be the absence of specific guidelines for staffing for procedures performed after-hours. Recent Canadian guidelines recommended that "endoscopy facilities should have the technical and personnel resources required by national and/or regional standards to complete all planned procedures safely and effectively" (1). However, there are few national and/or regional standards for 
TABLE 1

Practice location of the respondents

\begin{tabular}{lccrr}
\hline & \multicolumn{3}{c}{ Province } & \\
\cline { 2 - 4 } & Ontario & Alberta & $\begin{array}{c}\text { British } \\
\text { Columbia }\end{array}$ & $\begin{array}{r}\text { Rest of } \\
\text { Canada }\end{array}$ \\
\hline Practice location & & & & \\
$\quad$ University & $37(60.5)$ & $22(69)$ & $14(50)$ & $23(72)$ \\
$\quad$ Community & $24(40)$ & $10(31)$ & $14(50)$ & $9(28)$ \\
$\begin{array}{l}\text { Population of the city of practice } \\
\quad<250,000\end{array}$ & $17(25)$ & $2(6)$ & $12(38)$ & $14(40)$ \\
250,001 to $1,000,000$ & $27(40)$ & $6(19)$ & $7(22)$ & $13(37)$ \\
$>1,000,000$ & $24(35)$ & $24(75)$ & $13(41)$ & $8(23)$ \\
All respondents & $68(41)$ & $33(20)$ & $32(19)$ & $35(21)$ \\
CAG membership database & $187(44)$ & $74(17)$ & $50(12)$ & $116(27)$ \\
\hline
\end{tabular}

Data presented as n (\%). CAG Canadian Association of Gastroenterology

TABLE 2

Practice of after-hours endoscopy by adult and pediatric gastroenterologists

\begin{tabular}{|c|c|c|c|}
\hline & \multicolumn{2}{|c|}{ Gastroenterologist } & \multirow[b]{2}{*}{$\mathbf{P}$} \\
\hline & Adult & Pediatric & \\
\hline \multicolumn{4}{|l|}{ Practice location } \\
\hline University & $75(58)$ & $17(100)$ & $<0.01$ \\
\hline Community & $54(42)$ & $0(0)$ & \\
\hline \multicolumn{4}{|c|}{ Endoscopy nurse assistance outside unit } \\
\hline Yes & $119(86)$ & $11(61)$ & 0.08 \\
\hline No & $17(12)$ & $3(17)$ & \\
\hline$N / A^{*}$ & $2(1)$ & $4(22)$ & \\
\hline \multicolumn{4}{|c|}{ Where after-hours endoscopy is performed } \\
\hline Emergency room & $106(82)$ & $2(12)$ & $<0.01$ \\
\hline Endoscopy suite & $79(61)$ & $3(18)$ & $<0.01$ \\
\hline Intensive care unit & $111(86)$ & $6(35)$ & $<0.01$ \\
\hline Coronary care unit & $56(43)$ & $0(0)$ & $<0.01$ \\
\hline Step-down units & $34(26)$ & $0(0)$ & 0.03 \\
\hline Operating room & $34(26)$ & $12(70)$ & $<0.01$ \\
\hline Wards & $6(5)$ & $0(0)$ & 1.00 \\
\hline Other & $3(2.5)$ & $0(0)$ & 1.00 \\
\hline \multicolumn{4}{|c|}{ Who is present for after-hours endoscopy? } \\
\hline 1 Registered nurse & $87(64)$ & $8(47)$ & 0.14 \\
\hline 2 Registered nurses & $37(28)$ & $5(29)$ & 0.55 \\
\hline $\begin{array}{l}\text { LPN, respiratory therapist, nursing } \\
\text { or endoscope assistant }\end{array}$ & $21(16)$ & $5(29)$ & 0.16 \\
\hline Resident & $45(35)$ & $8(47)$ & 0.28 \\
\hline Anesthetist or another physician & $9(7)$ & $11(65)$ & $<0.01$ \\
\hline $\begin{array}{l}\text { Emergency/intensive care unit } \\
\text { nurse }\end{array}$ & 2 & $0(0)$ & 1.00 \\
\hline Operating room nurse & $0(0)$ & $4(24)$ & $<0.01$ \\
\hline \multicolumn{4}{|c|}{ Is a trained endoscopy nurse always available? } \\
\hline Yes & $80(62)$ & $2(12)$ & 0.01 \\
\hline No & $59(38)$ & $15(88)$ & \\
\hline \multicolumn{4}{|c|}{ How often is an endoscopy nurse called in? } \\
\hline Everyday & $1(1)$ & $0(0)$ & 1.00 \\
\hline 5-6 times per week & $17(13)$ & $0(0)$ & 0.22 \\
\hline 3-4 times per week & $38(29.5)$ & $0(0)$ & 0.01 \\
\hline 1-2 times per week & $26(20)$ & $2(12)$ & 0.74 \\
\hline 1-2 times per month & $10(8)$ & $2(12)$ & 0.63 \\
\hline$<1-2$ times per month & $4(3)$ & $2(12)$ & 0.14 \\
\hline N/A (No on-call endoscopy nurse) & $33(26)$ & $11(65)$ & $<0.01$ \\
\hline
\end{tabular}

TABLE 2 - CONTINUED

Practice of after-hours endoscopy by adult and pediatric gastroenterologists

\begin{tabular}{|c|c|c|c|}
\hline & \multicolumn{2}{|c|}{ Gastroenterologist } & \multirow[b]{2}{*}{$\mathbf{P}$} \\
\hline & Adult & Pediatric & \\
\hline \multicolumn{4}{|c|}{ How often does a resident/fellow assist?, \% } \\
\hline Never $(0)$ & $57(44)$ & $4(24)$ & 0.19 \\
\hline $1-24$ & $14(11)$ & $2(12)$ & 0.69 \\
\hline $25-49$ & $14(11)$ & $2(12)$ & 0.69 \\
\hline $50-74$ & $5(4)$ & $3(18)$ & 0.05 \\
\hline 75-99 & $22(17)$ & $5(29)$ & 0.19 \\
\hline Always (100) & $17(13)$ & $1(6)$ & 0.69 \\
\hline \multicolumn{4}{|c|}{ Who cleans and reprocesses the endoscope after hours? } \\
\hline Central reprocessing unit & $61(46)$ & $15(88)$ & $<0.01$ \\
\hline Resident & $10(8)$ & $0(0)$ & 0.60 \\
\hline Endoscopist & $8(6)$ & $2(12)$ & 0.33 \\
\hline Nurse & $43(35)$ & $1(6)$ & 0.02 \\
\hline $\begin{array}{l}\text { Endoscopy aide, technician or } \\
\text { cleaner }\end{array}$ & $19(14)$ & $0(0)$ & 0.13 \\
\hline Others & $5(4)$ & $1(6)$ & 0.52 \\
\hline \multicolumn{4}{|c|}{ Time reserved on each working day for emergency cases, $\mathrm{h}$} \\
\hline Nil & $16(12)$ & $9(53)$ & $<0.01$ \\
\hline 0.5 & $14(11)$ & $1(6)$ & 1.00 \\
\hline $1-1.5$ & $25(12)$ & $1(6)$ & 0.69 \\
\hline $2-3$ & $30(22)$ & $0(0)$ & 0.03 \\
\hline$>3-4$ & $7(5)$ & $0(0)$ & 1.00 \\
\hline$>4$ & $15(11)$ & $0(0)$ & 0.22 \\
\hline Variable & $13(10)$ & $6(35)$ & $<0.01$ \\
\hline All day & $8(6)$ & $0(0)$ & 0.60 \\
\hline \multicolumn{4}{|l|}{ Access to propofol } \\
\hline Yes & $47(38)$ & $15(94)$ & $<0.01$ \\
\hline No & $77(62)$ & $1(6)$ & \\
\hline \multicolumn{4}{|l|}{ Access to intensive care unit beds } \\
\hline Yes & $108(87)$ & $15(94)$ & 0.69 \\
\hline No & $16(13)$ & $1(6)$ & \\
\hline \multicolumn{4}{|c|}{ Able to arrange an endoscopy within $24 \mathrm{~h}$} \\
\hline Yes & $120(97)$ & $14(88)$ & 0.14 \\
\hline No & $4(3)$ & $2(13)$ & \\
\hline \multicolumn{4}{|c|}{ Satisfaction rating with current arrangements for after-hours endoscopy } \\
\hline Low (1-4) & $30(23)$ & $7(44)$ & 0.12 \\
\hline Moderate (5-7) & $31(24)$ & $7(44)$ & 0.13 \\
\hline High (8-10) & $69(53)$ & $2(12)$ & $<0.01$ \\
\hline
\end{tabular}

Data presented as $n(\%)$ unless otherwise indicated. ${ }^{*}$ N/A Not applicable (do not perform endoscopy outside of the endoscopy unit). LPN Licensed practical nurse

staffing for endoscopy, particularly for after-hours endoscopy. Therefore, we recommend that the CAG develop a position statement with regard to the minimum staffing requirements for performance of gastrointestinal endoscopy in Canada; this should be developed with input from patients and accreditation agencies. In 2010, the American Society for Gastrointestinal Endoscopy issued a position statement for staffing during gastrointestinal endoscopy, but did not specifically address after-hours or emergency endoscopy (5).

Another potential reason for differences in staffing patterns is that few studies have objectively evaluated the effect of differences in staffing on important patient outcomes. A single study reported that the presence of experienced nurses increased the polyp detection rate during routine screening colonoscopy (6). Similar studies are urgently needed, especially in these uncertain economic times when there may be impetus to reduce/minimize staffing levels.

Our survey found that one in 10 endoscopists or their residents are reprocessing the endoscopes themselves. We hope the hospitals are ensuring such physicians are receiving adequate and regular 
TABLE 3

Practice of after-hours endoscopy at university and community hospitals

\begin{tabular}{|c|c|c|c|}
\hline & \multicolumn{2}{|c|}{ Hospital } & \multirow[b]{2}{*}{$\mathbf{P}$} \\
\hline & University & Community & \\
\hline \multicolumn{4}{|c|}{ Endoscopy nurse assistance outside unit } \\
\hline Yes & $67(86)$ & $51(89)$ & 0.61 \\
\hline No & $11(14)$ & $6(11)$ & \\
\hline
\end{tabular}

Where after-hours endoscopy is performed

$\begin{array}{lccr}\text { Operating room } & 19(24) & 16(28) & 0.05 \\ \text { Endoscopy suite } & 50(64) & 32(56) & 0.38 \\ \text { Emergency room } & 71(91) & 38(67) & <0.01 \\ \text { Intensive care unit } & 71(91) & 42(74) & 0.01 \\ \text { Coronary care unit } & 43(55) & 13(23) & <0.01 \\ \text { Step down units } & 29(37) & 6(10) & <0.01 \\ \text { Wards } & 6(8) & 0(0) & 0.04 \\ \text { Other } & 2(2.5) & 3(5) & 0.65 \\ \text { Who is present for after-hours endoscopy? } & & \\ \begin{array}{l}\text { 1 Registered nurse } \\ 2 \text { Registered nurses }\end{array} & 57(73) & 28(49) & 0.01 \\ \text { LPN, respiratory therapist, } & 13(16) & 27(47) & <0.01 \\ \quad \text { nursing or endoscopy assistant } & 14(18) & 8(14) & 0.64 \\ \text { Resident } & 45(58) & 2(4) & <0.01 \\ \text { Anesthetist or another physician } & 2(3) & 7(12) & 0.04 \\ \text { ER/intensive care unit nurse } & 1(1) & 1(2) & 1.00 \\ \text { Is trained endoscopy nurse always available? } & & \\ \text { Yes } & 50(64) & 32(56) & 0.38 \\ \text { No } & 28(36) & 25(44) & \end{array}$

How often is an on-call endoscopy nurse called in?

$\begin{array}{lccc}\text { Everyday } & 1(1) & 0(0) & 1.00 \\ 5-6 \text { times per week } & 14(18) & 3(5) & 0.04 \\ \text { 3-4 times per week } & 25(32) & 14(25) & 0.44 \\ 1-2 \text { times per week } & 16(21) & 11(19) & 1.00 \\ 1-2 \text { times per month } & 3(4) & 7(12) & 0.10 \\ <1-2 \text { times per month } & 1(1) & 4(7) & 0.16 \\ \text { N/A (no on-call endoscopy } & 18(23) & 18(32) & 0.33\end{array}$
nurse)

How often does a resident/fellow assist?

\begin{tabular}{|c|c|c|c|}
\hline Never & $10(13)$ & $50(88)$ & $<0.01$ \\
\hline $1-24$ & $10(13)$ & $5(9)$ & 0.58 \\
\hline $25-49$ & $13(17)$ & $1(2)$ & $<0.01$ \\
\hline $50-74$ & $4(5)$ & $1(2)$ & 0.40 \\
\hline 75-99 & $23(29)$ & $0(0)$ & $<0.01$ \\
\hline Always & $18(33)$ & $0(0)$ & $<0.01$ \\
\hline \multicolumn{4}{|c|}{ Who cleans and reprocesses the endoscope after hours? } \\
\hline $\begin{array}{l}\text { Central reprocessing unit of } \\
\text { the hospital }\end{array}$ & $31(40)$ & $33(58)$ & 0.05 \\
\hline Resident & $11(14)$ & $0(0)$ & 0.01 \\
\hline Endoscopist & $4(5)$ & $4(7)$ & 0.72 \\
\hline Nurse & $31(40)$ & $17(30)$ & 0.36 \\
\hline $\begin{array}{l}\text { Endoscopy aide, technician } \\
\text { or cleaner }\end{array}$ & $12(15)$ & $7(12)$ & 0.28 \\
\hline Others & $3(4)$ & $2(4)$ & 1.00 \\
\hline
\end{tabular}

Time reserved on each working day for emergency cases, $\mathrm{h}$

$\begin{array}{lrcl}\text { Nil } & 14(18) & 4(7) & 0.08 \\ 0.5 & 8(10) & 7(12) & 0.78 \\ 1-1.5 & 17(22) & 8(14) & 0.84 \\ 2-3 & 18(23) & 15(26) & 0.69 \\ >3-4 & 6(8) & 2(4) & 0.47 \\ >4 & 7(9) & 5(9) & 1.00\end{array}$

TABLE 3 - CONTINUED

Practice of after-hours endoscopy at university and community hospitals

\begin{tabular}{|c|c|c|c|}
\hline & \multicolumn{2}{|c|}{ Hospital } & \multirow[b]{2}{*}{$\mathbf{P}$} \\
\hline & University & Community & \\
\hline Variable & $8(10)$ & $6(11)$ & 1.00 \\
\hline All day & $7(9)$ & $0(0)$ & 0.02 \\
\hline \multicolumn{4}{|l|}{ Access to propofol } \\
\hline Yes & $23(31)$ & $26(47)$ & 0.07 \\
\hline No & $52(69)$ & $29(53)$ & \\
\hline \multicolumn{4}{|l|}{ Access to intensive care unit beds } \\
\hline Yes & $67(80)$ & $46(84)$ & 0.43 \\
\hline No & $8(20)$ & $9(16)$ & \\
\hline \multicolumn{4}{|l|}{ Who receives transfers } \\
\hline Endoscopy team via ER & $22(29)$ & $22(40)$ & 0.19 \\
\hline $\begin{array}{l}\text { Endoscopy team-patients come } \\
\text { directly to endoscopy suite }\end{array}$ & $3(4)$ & $2(4)$ & 1.00 \\
\hline ER physician & $21(28)$ & $11(20)$ & 0.41 \\
\hline Internal medicine & $15(20)$ & $3(5)$ & 0.02 \\
\hline Intensive care unit & $11(15)$ & $10(18)$ & 0.63 \\
\hline Other & $3(4)$ & $6(11)$ & 0.17 \\
\hline \multicolumn{4}{|c|}{ Able to arrange emergency endoscopy within $24 \mathrm{~h}$} \\
\hline Yes & $75(100)$ & $51(93)$ & 0.03 \\
\hline No & $0(0)$ & $4(7)$ & \\
\hline \multicolumn{4}{|c|}{ Proportion of emergency endoscopies performed within $24 \mathrm{~h}, \%$} \\
\hline $11-25$ & $0(0)$ & $2(4)$ & 0.18 \\
\hline $26-50$ & $3(4)$ & $1(2)$ & 0.64 \\
\hline $51-75$ & $19(25)$ & $14(25)$ & 1.00 \\
\hline $76-100$ & $53(71)$ & $38(69)$ & 0.85 \\
\hline \multicolumn{4}{|l|}{ On call schedule for ERCPs } \\
\hline Yes & $36(48)$ & $16(29)$ & 0.03 \\
\hline No & $39(52)$ & $39(71)$ & \\
\hline \multicolumn{4}{|l|}{ Satisfaction rating } \\
\hline Low (1-4) & $18(24)$ & $12(22)$ & 0.06 \\
\hline Moderate (5-7) & $15(20)$ & $16(29)$ & 0.30 \\
\hline High (8-10) & $42(56)$ & 27 (49) & 0.48 \\
\hline
\end{tabular}

Data presented as $n$ (\%) unless otherwise indicated. ER Emergency room; ERCP Endoscopic retrograde cholangiopancreatography; LPN Licensed practical nurse; N/A Not applicable

TABLE 4

Practice of after-hours endoscopy in the different provinces

\begin{tabular}{|c|c|c|c|c|c|}
\hline & \multicolumn{3}{|c|}{ Province } & \multirow[b]{2}{*}{$\begin{array}{l}\text { Rest of } \\
\text { Canada }\end{array}$} & \multirow[b]{2}{*}{$\mathbf{P}$} \\
\hline & Ontario & Alberta & $\begin{array}{l}\text { British } \\
\text { Columbia }\end{array}$ & & \\
\hline \multicolumn{6}{|c|}{ Endoscopy nurse assistance outside unit } \\
\hline Yes & $45(74)$ & $25(96)$ & $27(93)$ & $28(90)$ & 0.06 \\
\hline No & $13(21)$ & $0(0)$ & $2(7)$ & $3(10)$ & \\
\hline$N / A^{*}$ & $3(5)$ & $1(4)$ & $0(0)$ & $0(0)$ & \\
\hline \multicolumn{6}{|c|}{ Where after-hours endoscopy is performed } \\
\hline ER & $46(82)$ & $24(100)$ & $23(85)$ & $16(52)$ & $<0.01$ \\
\hline Endoscopy suite & $22(39)$ & $23(96)$ & $19(70)$ & $18(58)$ & $<0.01$ \\
\hline $\mathrm{ICU}$ & $48(86)$ & $24(100)$ & $21(78)$ & $20(65)$ & 0.02 \\
\hline $\mathrm{CCU}$ & $23(41)$ & $15(15)$ & $11(41)$ & $7(23)$ & 0.06 \\
\hline Step down units & $21(38)$ & $2(8)$ & $6(22)$ & $6(19)$ & 0.07 \\
\hline OR & $23(41)$ & $7(29)$ & $1(4)$ & $4(13)$ & $<0.01$ \\
\hline Wards & $5(9)$ & $1(4)$ & $0(0)$ & $0(0)$ & 0.39 \\
\hline Other & $1(2)$ & $1(4)$ & 3 (11) & $0(0)$ & 0.37 \\
\hline
\end{tabular}


TABLE 4 - CONTINUED

Practice of after-hours endoscopy in the different provinces

\begin{tabular}{lrrrrr}
\hline & \multicolumn{3}{c}{ Province } & \\
\cline { 2 - 5 } & Ontario & Alberta & $\begin{array}{c}\text { British } \\
\text { Columbia }\end{array}$ & $\begin{array}{c}\text { Rest of } \\
\text { Canada }\end{array}$ & P \\
\hline 1 RN & $39(65)$ & $17(77)$ & $17(68)$ & $11(38)$ & 0.05 \\
$2 \mathrm{RNs}$ & $12(18)$ & $8(37)$ & $4(16)$ & $15(50)$ & 0.02 \\
$\begin{array}{l}\text { LPN, RT, nursing or } \\
\text { endoscopy assistant }\end{array}$ & $6(10)$ & $7(32)$ & $2(8)$ & $2(7)$ & 0.09 \\
$\quad \begin{array}{l}\text { Resident } \\
\text { Anesthetist or }\end{array}$ & $25(42)$ & $8(36)$ & $7(28)$ & $7(24)$ & 0.52 \\
$\quad$ physician & $8(13)$ & $0(0)$ & $0(0)$ & $1(3)$ & 0.17 \\
$\quad$ ER/ICU nurse & $0(0)$ & $0(0)$ & $1(4)$ & $1(3)$ & 0.95 \\
Other & $1(1.5)$ & $3(14)$ & $1(4)$ & $0(0)$ & 0.22
\end{tabular}

Is a trained endoscopy nurse always available?

$\begin{array}{lccccc}\text { Yes } & 28(51) & 25(96) & 13(50) & 26(93) & <0.01 \\ \text { No } & 27(49) & 1(4) & 13(50) & 2(7) & \end{array}$

How often is an on-call endoscopy nurse called in?

$\begin{array}{lrclcr}\text { Everyday } & 0(0) & 1(4) & 0(0) & 0(0) & 0.70 \\ \text { 5-6 times/week } & 4(7) & 6(23) & 2(8) & 5(18) & 0.36 \\ \text { 3-4 times/week } & 8(15) & 12(46) & 8(31) & 11(39) & 0.03 \\ \text { 1-2 times/week } & 10(18) & 6(23) & 6(23) & 5(18) & 0.99 \\ \text { 1-2 times/month } & 7(13) & 0(0) & 2(8) & 1(4) & 0.40 \\ <1-2 \text { times/month } & 1(2) & 1(4) & 2(8) & 1(4) & 0.82 \\ \text { N/A* } & 25(45) & 0(0) & 6(23) & 5(18) & <0.01\end{array}$

How often does a resident/fellow assist?, \%

$\begin{array}{lrllll}\text { Never (0) } & 25(45) & 5(19) & 17(65) & 13(46) & 0.02 \\ 1-24 & 2(4) & 6(23) & 3(12) & 4(14) & 0.16 \\ 25-49 & 2(4) & 4(15) & 5(19) & 3(11) & 0.30 \\ 50-74 & 1(2) & 2(8) & 1(4) & 1(4) & 0.85 \\ 75-99 & 13(24) & 6(23) & 0(0) & 4(14) & 0.12 \\ \text { Always (100) } & 12(22) & 3(11.5) & 0(0) & 3(11) & 0.13\end{array}$

Who cleans and reprocesses the endoscope after hours?

$\begin{array}{lrrrrr}\begin{array}{l}\text { Central } \\ \text { reprocessing unit }\end{array} & 27(56) & 5(29) & 22(78) & 10(37) & 0.01 \\ \text { Resident } & 9(19) & 0(0) & 0(0) & 2(7) & 0.08 \\ \text { Endoscopist } & 3(6) & 0(0) & 5(18) & 0(0) & 0.14 \\ \quad \text { Nurse } & 17(35) & 13(76) & 7(25) & 17(63) & <0.01 \\ \begin{array}{l}\text { Endoscopy aid, } \\ \quad \text { technician or }\end{array} & 6(13) & 9(53) & 1(4) & 2(7) & <0.01 \\ \quad \text { cleaner } & & & & & \\ \text { Others } & 4(8) & 0(0) & 1(4) & 1(4) & 0.87\end{array}$

Time reserved on each working day for emergency cases, $\mathrm{h}$

$\begin{array}{lccccc}\text { Nil } & 6(11) & 5(19) & 2(8) & 5(18) & 0.42 \\ 0.5 & 7(13) & 0(0) & 3(12) & 5(18) & 0.39 \\ 1-1.5 & 13(23) & 0(0) & 6(23) & 7(24) & 0.13 \\ 2-3 & 12(21) & 9(35) & 6(23) & 6(21) & 0.75 \\ >3-4 & 4(7) & 3(12) & 1(4) & 0(0) & 0.66 \\ >4 \text { and half days } & 5(9) & 4(15) & 2(8) & 1(4) & 0.74 \\ \text { Variable } & 5(9) & 4(15) & 2(8) & 2(7) & 0.92 \\ \text { All day } & 3(5) & 0(0) & 4(15) & 2(7) & 0.39 \\ \text { Access to propofol } & & & & & \\ \text { Yes } & 26(50) & 7(28) & 6(24) & 10(36) & 0.18 \\ \text { No } & 26(50) & 18(72) & 19(76) & 18(74) & \\ \text { Access to ICU beds } & & & & & \\ \text { Yes } & 48(92) & 20(80) & 21(84) & 24(86) & \\ \text { No } & 4(8) & 5(20) & 4(16) & 4(14) & 0.69\end{array}$

TABLE 4 - CONTINUED

Practice of after-hours endoscopy in the different provinces

\begin{tabular}{lccccc}
\hline & \multicolumn{5}{c}{ Province } \\
\cline { 2 - 5 } & Ontario & Alberta & $\begin{array}{c}\text { British } \\
\text { Columbia }\end{array}$ & $\begin{array}{c}\text { Rest of } \\
\text { Canada }\end{array}$ & P \\
\hline $\begin{array}{l}\text { Endoscopy team } \\
\text { via ER }\end{array}$ & $15(29)$ & $10(40)$ & $12(48)$ & $5(18)$ & 0.19 \\
ER physician & $4(8)$ & $12(48)$ & $5(20)$ & $11(39)$ & $<0.01$ \\
Internal medicine & $6(12)$ & $1(4)$ & $4(16)$ & $7(25)$ & 0.33 \\
ICU & $15(29)$ & $1(4)$ & $0(0)$ & $3(11)$ & 0.01 \\
Other & $5(10)$ & $1(4)$ & $2(8)$ & $0(0)$ & 0.68 \\
Able to arrange emergency endoscopy within $24 \mathrm{~h}$ & & \\
Yes & $50(96)$ & $25(100)$ & $24(96)$ & $27(96)$ & 0.95 \\
No & $2(4)$ & $0(0)$ & $1(4)$ & $1(4)$ &
\end{tabular}

Proportion of emergency endoscopies performed within $24 \mathrm{~h}, \%$

$\begin{array}{lccccc}11-25 & 2(4) & 0(0) & 0(0) & 0(0) & 0.87 \\ 26-50 & 2(4) & 1(4) & 0(0) & 1(4) & 0.95 \\ 51-75 & 18(35) & 3(12) & 8(32) & 4(14) & 0.19 \\ 76-100 & 30(58) & 21(84) & 17(68) & 23(82) & 0.04\end{array}$

On call schedule for ERCPs

\begin{tabular}{lrrrrr} 
Yes & $10(19)$ & $22(88)$ & $9(36)$ & $11(39)$ & $<0.01$ \\
$\quad$ No & $42(81)$ & $3(12)$ & $16(64)$ & $17(61)$ & \\
Satisfaction rating & & & & & \\
Low (1-4) & $19(37)$ & $0(0)$ & $7(28)$ & $4(14)$ & 0.01 \\
Moderate (5-7) & $12(23)$ & $4(16)$ & $6(24)$ & $9(32)$ & 0.76 \\
High (8-10) & $21(40)$ & $21(84)$ & $12(48)$ & $15(54)$ & 0.01 \\
\hline
\end{tabular}

Data presented as $n(\%)$ unless otherwise indicated. *N/A Not applicable (do not perform endoscopy outside of the endoscopy unit). CCU Coronary care unit ER Emergency room; ERCP Endoscopic retrograde cholangiopancreatography; ICU Intensive care unit; OR Operating room; RN Registered nurse; RT Respiratory therapist; LPN Licensed practical nurse

training for all of the components of reprocessing to continue to do so. Otherwise, they could be putting their patients at risk. For endoscopy units outside of the hospital in some provinces (ie, BC), only fully trained 'ticketed' reprocessing technicians are permitted to clean the instruments even during the daytime procedures. Residents reprocessing endoscopes regularly at the university hospitals raises questions as to whether that is part of their training or inappropriate delegation of routine clinical activities with limited learning gains for the residents (as used to occur with residents transporting patients).

Our study has a few limitations. First, as with all surveys, the study was limited by the response rate and recall by the respondents. However, we achieved a response rate higher than most other electronic surveys and the respondents' characteristics were similar to those of the CAG membership database. Our survey was limited to the CAG membership and, hence, we did not evaluate practices in parts of the country where endoscopy is primarily performed by surgeons (7).

\section{CONCLUSION}

The present survey suggests a large regional variation in the provision of after-hours endoscopy in Canada, with respect to support of trained staff, endoscope reprocessing by trained staff and access to urgent endoscopy within $24 \mathrm{~h}$. In the absence of data regarding the effect of different levels of staffing on patient outcomes, consensusbased standards on minimum levels of appropriate staffing for afterhours endoscopy should form the basis for ensuring that all patients have access to appropriate care, irrespective of where it is provided. 


\section{REFERENCES}

1. Armstrong D, Barkun A, Bridges R, et al. Canadian Association of Gastroenterology consensus guidelines on safety and quality indicators in endoscopy. Can J Gastroenterol 2012;26:17-31.

2. Barkun AN, Bardou M, Kuipers EJ, et al. International consensus recommendations on the management of patients with nonvariceal upper gastrointestinal bleeding. Ann Intern Med 2010;152:101-13.

3. Porostocky P, Chiba N, Colacino P, Sadowski D, Singh H. A survey of sedation practices for colonoscopy in Canada. Can J Gastroenterol 2011;25:255-60.

4. Petersen BT. Promoting efficiency in gastrointestinal endoscopy. Gastrointest Endosc Clin N Am 2006;16:671-85.
5. Jain R, Ikenberry SO, Anderson MA, et al. Minimum staffing requirements for the performance of GI endoscopy. Gastrointest Endosc 2010;72:469-70.

6. Dellon ES, Lippmann QK, Sandler RS, Shaheen NJ.

Gastrointestinal endoscopy nurse experience and polyp detection during screening colonoscopy. Clin Gastroenterol Hepatol 2008;6:1342-7.

7. Hilsden RJ, Tepper J, Moayyedi P, Rabeneck L. Who provides gastrointestinal endoscopy in Canada? Can J Gastroenterol 2007;21:843-6. 


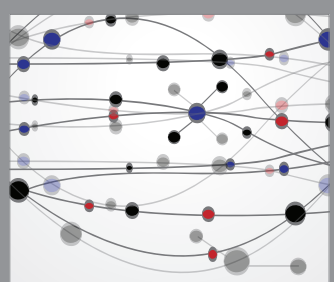

The Scientific World Journal
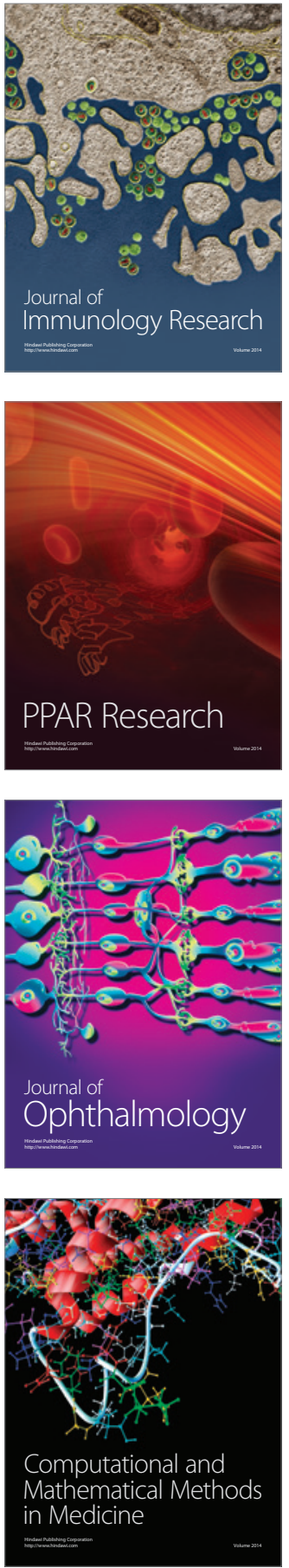

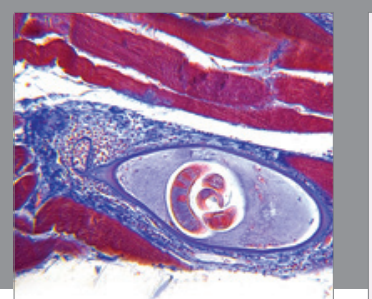

Gastroenterology Research and Practice

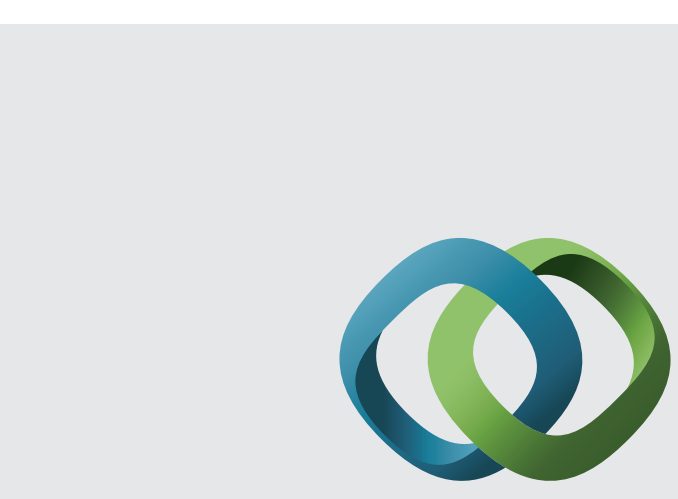

\section{Hindawi}

Submit your manuscripts at

http://www.hindawi.com
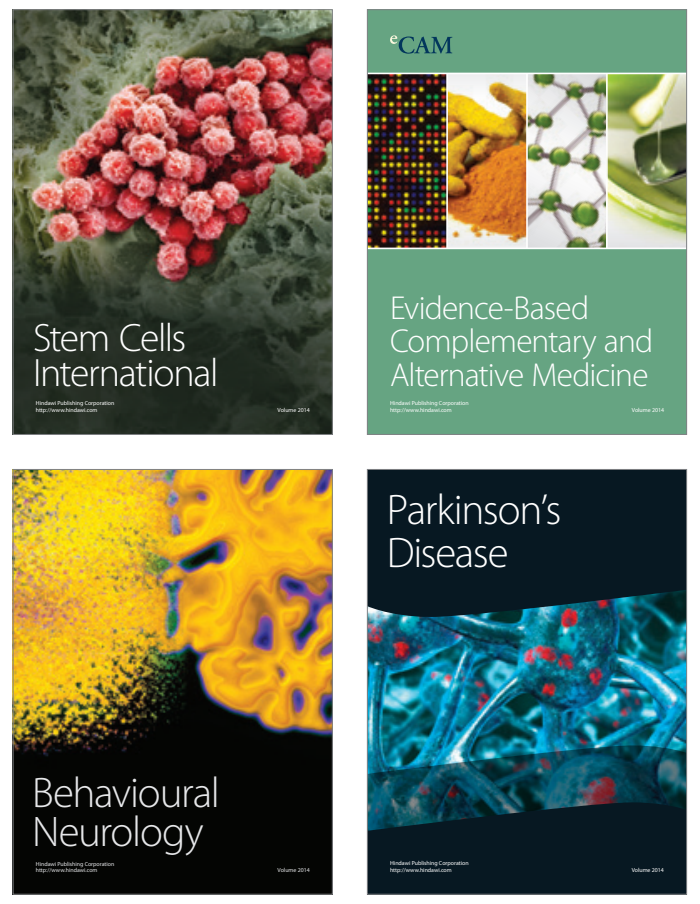
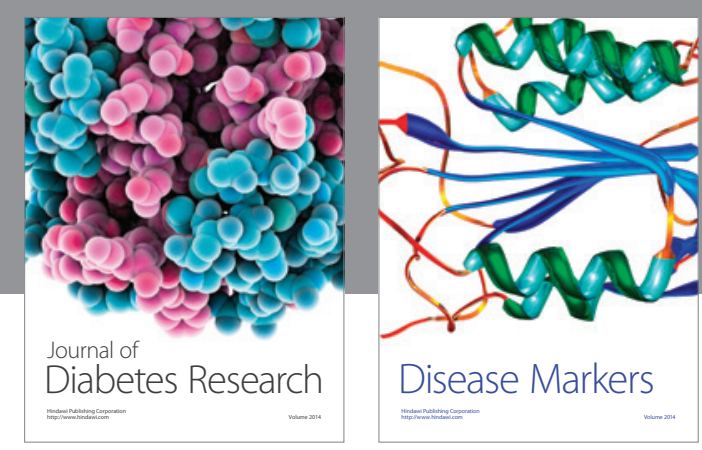

Disease Markers
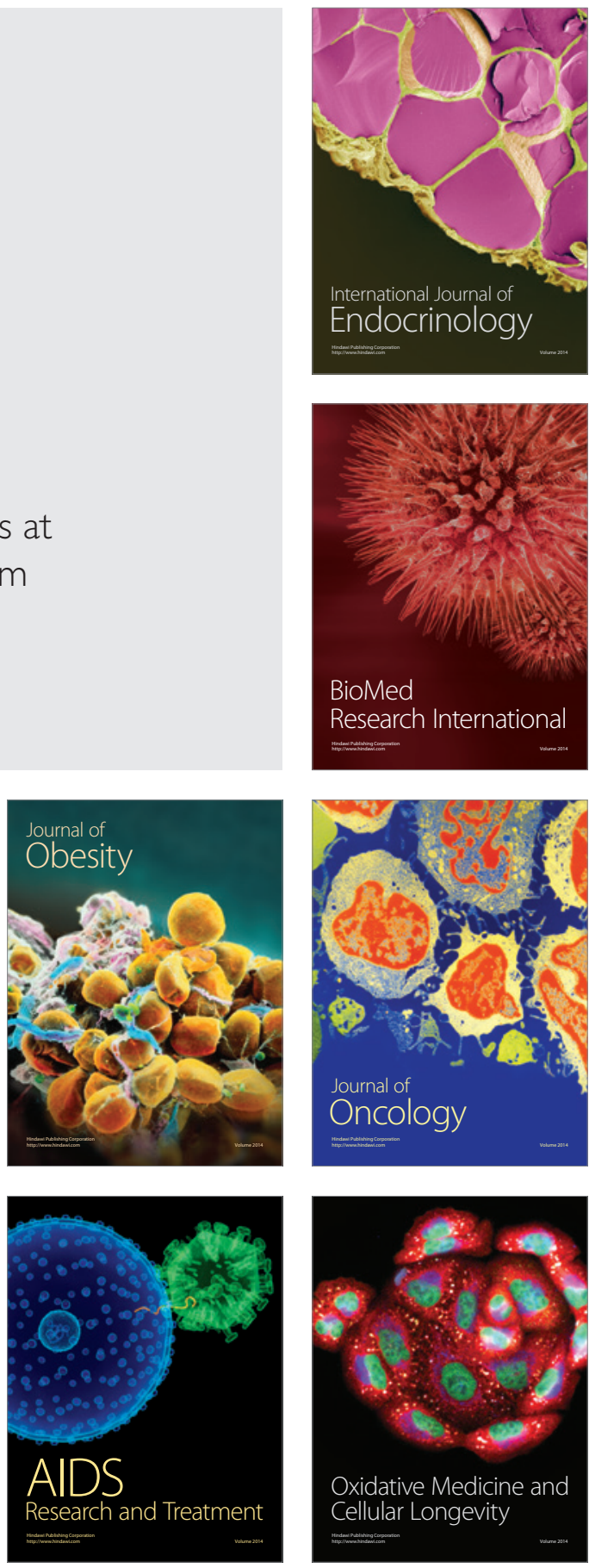